\title{
Sensations from Surgically Transferred Glabrous Skin; Central Versus Peripheral Factors
}

\author{
R. W. DYKES, J.K. TERZIS, AND B. STRAUCH
}

SUMMARY: In reinnervated skin transferred from the foot to the hand, sensory thresholds approach normal values - an observation not predicted by the theoretical relationship between innervation density and tactile acuity. Therefore, we suggest that innervation density is not the major factor determining tactile acuity. Rather, the hand region of the central somesthetic map may be specialized to provide a calibre of function unavailable to other regions.

RESUME: Dans la peau réinnervée transférée du pied à la main, les seuils sensitifs approchent les valeurs normales - une observation imprévisible selon les interrelations théoriques entre la densité d'innervation et l'acuité tactile. Nous suggérons donc que la densité d'innervation n'est pas le facteur principal déterminant l'acuité tactile. La région de la main dans le territoire somesthésique central serait plutôt spécialisée à fournir un éventail de fonctions non disponibles dans d'autres régions du corps.
From the Microsurgical Research Laboratories Department of Surgery. Royal Victoria Hospital, McGill University, Montreal, Quebec and the Department of Plastic Surgery, Montefiore Hospital and Medical Center, Albert Einstein School of Medicine of Yeshiva University, Bronx, New York.

Reprint requests to: Dr. R. W. Dykes, Microsurgica Research Laboratories. Dept. of Surgery. Royal Victoria Hospital, 687 Pine Ave. West, Montreal H $3 A$ IAl Canada.

\section{INTRODUCTION}

Tactile acuity is best on the tips of the fingers and poorest on the back. This difference is assumed to be due to differences in the density of cutaneous innervation; the finest touch thresholds and two-point discriminations are made in those areas having the most dense innervation (Bolton et al., 1966; Boring, 1942; Cauna, 1956; Hoepke, 1958; Ridley, 1968; Sinclair, 1967; Weinstein, 1968). Different densities of innervation are also used to explain distortions observed in maps of central sensory representations (von Bekésy, 1959; Lindblom and Lindstrom, 1976; Ruch, 1955; Weber, 1852). Neurophysiologists have proposed that parts of these maps have enlarged to a degree which is proportional to the innervation density of the body part being represented (Mountcastle, 1974). However, in the visual system, recent data comparing retinal ganglion cell densities and cortical representation in the owl monkey suggest that the relative areas of portions of the cortical map are not governed solely by peripheral receptor density. The magnification factor for the foveal portion of the primary visual cortex is far greater than is needed to maintain the proportionality between peripheral innervation density and cortical area. Thus, Meyerson et al. (1977) proposed that some portions of the visual cortex were specialized to serve one part of the retina in a way which was different from the rest.

We report psychophysical observations made following surgical transfer of glabrous skin from one part of the body to another which suggest that the hand portion of the somatosensory system also is specialized, and that this specialization provides an enhanced tactile capacity for the hand. We argue that the tactile acuity may depend upon a central specialization as well as upon innervation density.

A novel microsurgical procedure permits surgeons to transfer a large tissue mass containing vessels which are attached to recipient vessels in the new site and nerves which are attached to nerve stumps. The tissue becomes revascularized immediately and an opportunity is provided for return of sensory and motor function (Daniel and Taylor, 1973; Daniel et al., 1976). A region of glabrous skin from the foot has recently been identified which is suitable for covering cutaneous defects of the hand (Gilbert et al.. 1975; Gilbert, 1976). Our report concerns the remarkable return of sensory function displayed by two patients who had such transfers of neurovascular free flaps of glabrous skin (Strauch and Tzur, 1978).

\section{METHODS}

Two middle-aged adult males (A and $B$ ) each received traumatic injuries leading to amputation of the tips of their fingers and the loss of the glabrous skin over portions of the volar surfaces of one hand. Through a multi-stage surgical procedure these hands were reconstructed to provide a pinching grip between the thumb and the remaining digits. In order to provide sensation for the reconstructed hand, the glabrous skin of the first web space from one foot was transferred to the anesthetic region in the hand and the nerves and vessels were connected to recipient nerves and vessels. The patients made an uneventful recovery.

Sensory performance was tested periodically by measuring: (1) pressure sensitivity, (2) the two-point discrimi- 
nation, and (3) the minimum distance required to recognize the direction of a moving stimulus. The pressure threshold was determined by the method of limits using an aesthesiometer (Rowan Products Co., Models RA100 and RA010, Panorama City, California). The two-point threshold was similarly determined using a calibrated caliper (Irex, \#Ir477, Toronto, Canada). Recognition of the direction of movement was tested with a blunt metal probe (Tip dia: $0.8 \mathrm{~mm}$ ). Movements from proximal to distal and distal to proximal were intermixed. Catch trials consisted of movements perpendicular to the proximodistal axis. A correct response on 3 of 4 trials was used as the criterion for threshold. After several months it became apparent that the sensory function in the transferred skin was remarkably good.

\section{RESULTS AND DISCUSSION}

The data in Table I were obtained at 22 and 23 months following the skin transfers. The degree of cutaneous sensibility approached that of normal digital skin and surpassed that seen in the web space of the contralateral foot. By these tests the reinnervated skin regions are essentially normal digital skin. That it is possible for a transferred skin region once having a 10 $\mathrm{mm}$ two-point threshold to acquire a 3 $\mathrm{mm}$ two-point threshold is an observation which cannot be accounted for with our present understanding of the somatosensory system.

Our preconceptions led us to expect that the sensory capability of the transferred skin region could never approach that of the normal skin because of such factors as: the loss of axons at the nerve anastomosis, a presumed lower pre-existing receptor density in the donor tissue, the failure of the regenerating axons to reinnervate some denervated and atrophic receptors, disorganized spatial relationships among the axons crossing the repair site, and the reinnervation of incorrect receptors (Terzis, 1977). Our observations indicate that some of the factors we presumed to contribute to a reduced sensory capacity are either not important or they do not occur in this situation. This leads us to question the

TABLE I

Sensory Tests of Glabrous Skin

\begin{tabular}{l|cc|cc|cc} 
& \multicolumn{2}{|c|}{$\begin{array}{c}\text { Normal } \\
\text { Foot }\end{array}$} & \multicolumn{2}{c|}{$\begin{array}{c}\text { Foot-to-hand } \\
\text { Transfer }\end{array}$} & \multicolumn{2}{c}{$\begin{array}{c}\text { Normal } \\
\text { Hand }\end{array}$} \\
\hline $\begin{array}{l}\text { VALUES FOR PATIENT } \\
\text { VON FREY HAIR } \\
\text { THRESHOLD (mg) }\end{array}$ & A & $\mathrm{B}^{*}$ & A & B & A & B \\
$\begin{array}{l}\text { TWO-POINT } \\
\text { DISCRIMINATION } \\
\text { THRESHOLD (mm) }\end{array}$ & 1500 & 2000 & 500 & 1000 & 300 & 300 \\
$\begin{array}{l}\text { DIRECTION OF } \\
\text { MOVING LINE (mm) }\end{array}$ & 18 & $18-18$ & $3-7$ & $6-14$ & $3-4$ & 4 \\
\hline
\end{tabular}

* Neurological examination and patient history suggest that there was some degree of alcoholic neuropathy present in this patient.

standard explanation that tactile acuity is solely a function of innervation density and to recognize that we do not know what factors control either the peripheral innervation density or the nature of the central sensory map. No relevant information has been published concerning the sensory capabilities of free flap transfers. The most analogous situation would be grafts of epidermis transferred to a new body site where they become revascularized and reinnervated. In this situation, skin grafts acquire some but not all of the sensory and histological characteristics of the recipient area (Ponten, 1960; Ridley, 1970). Two-point determinations and pressure thresholds approach those observed in adjacent normal skin.

Thus, from the meagre literature and our observations, it appears that the tactile sensation we measured can return to normal in some skin grafts as well as in glabrous skin flaps. In both situations the sensory capabilities of the transplanted skin approach those of the recipient site, in spite of the fact that the donor tissues were usually taken from areas of lower tactile capability having differences in receptor density and receptor type (Bolton et al., 1966; Boring, 1942; Cauna, 1956; Hoepke, 1958; Ponten, 1968; Ridley, 1968; Ridley, 1970; Sinclair, 1967; Weinstein, 1968).

It is difficult to reconcile our observations with current knowledge. Cortical evoked potentials can be produced by stimulation of one or two receptors (McIntyre et al., 1967), but this does not explain differences in receptor thresholds at different body sites. Tactile thresholds on the foot should be as low as those of the hand unless some central mechanism is involved.

Current explanations of a normal two-point test in the reinnervated skin require that two discriminately different populations of receptors activate different populations of cortical neurons which have specific spatial and functional connections among themselves (von Bekésy, 1959; Lindblom and Lindstrom, 1976; Ruch, 1955; Weber, 1852). Furthermore, the detection of the correct direction of a line drawn on the skin suggests that the appropriate spatial relationships were re-established among neural elements. Our observations suggest that there is either a mechanism (Gaze and Hope, 1976) for re-establishing pre-existing spatial relationships among the afferent fibers serving the skin or there is a dramatic and thorough re-organization of the central connections serving regenerated fibers.

To explain the surprisingly good tactile ability of our patients by generally accepted neurophysiological theory we must hypothesize that (i) innervation density in the hand is now greater than was the original innervation density when the skin was on the foot and (ii) some reorganization of central connections has occurred. 
Since there are many factors which might lead to the failure of some portion of the axons to return to the skin and the probability of some disorganization in spatial relationships among reconnected axons, we favor the alternative hypotheses that (i) innervation density is less important than we had presumed and (ii) that the functional characteristics of that portion of the somatosensory map which serves the hand are a more important factor for tactile acuity.

\section{REFERENCES}

VON BEKÉSY. G. (1959) Neural funneling along the skin and between the inner and outer hair cells of the cochlea. J. Acoust. Soc. Am. 21: 1236-1249.

BOI.TON. C.F., WINKELMAN. R.K. and DYCK. P. J. (1966) A quantitative study of Meissner's corpuscies in man. Neurology (Minn.) 16: 1-17.

BOI.TON, C.F., WINKELMAN, R.K. and DYCK. P. J. (1966) A quantitative study of Meissner's corpuscles in man. Neurology (Minn.) 16: 1-17.

BORING. E. G. (1942) Sensation and Perception in the History of Experimental Psychology. Appleton-Century-Crofts: New York.

CAUNA. N. (1965) Nerve supply and nerve endings in Meissner's corpuscles. Am. J. Anat. 99: 315-336.

DANIEL. R.K., and TAYLOR, G.I. (1973) Distant transfer of an island flap by microvascular anastomoses. A clinical technique. Plast. Reconstr. Surg. 52: 111-117.
DANIEL. R.K.. TERZIS. J.K. and MIDGLEY. D. (1976) Restoration of sensation to an anaesthetic hand by a free neurovascular flap from the foot. Plast. Reconstr. Surg. 57: 275-280.

GAZE. R.M. and HOPE. R.A. (1976) The formation of continuously ordered mappings. Prog. Brain Res. v. 45: Perspectives in Brain Research, ed., M.A. Corner and D.F. Swaab, Elsevier, N.Y.

GILBERT, A., MORRISON. W.. TUBIANA. R., LISFRANC, R. and FIRMIN, F. (1975) Transfert sur la main d'un lambeau libre sensible. Chirurgie 101: 691-694.

GILBERT. A. (1976) Composite tissue transfers from the foot: anatomic basis and surgical technique. In Symposium on Microsurgery. eds. A.I. Daniller and B. Strauch. C.V. Mosby Co.: St. Louis.

HOEPKE. H. (1958) New findings on the sensory innervation of the skin. Acta Neuroveg. 18: 49-59.

LINDBLOM, U. and LINDSTROM, B. (1976) Tactile thresholds of normal and blind subjects on stimulation of finger pads with short mechanical pulses of variable amplitude. In Sensory Functions of the Skin in Primates. Werner-Gren Center International Symposium Series. Vol. 27, ed. Y. Zotterman, Pergamon Press: London.

MAY, J. W. JR.. CHAIT, L. A.. COHEN. B. E. and O'BRIEN, B. McC. (1977) Free neurovascular flap from the first web of the foot in hand reconstruction. J. Hand Surg. 2: 387393.

MCINTYRE, A.K., HOLEMAN, M.E. and VEALE. J.L. (1967) Cortical responses to impulses from single Pacinian corpuscles in the cat's hind limb. Exp. Brain Res. 4: 243255.
MEYERSON. J.. MANIS. P.B., MIFZIN. F.M. and Al.L.MAN, J.M. (1977) Magnification in striate cortex and retinal ganglion cell layer of owl monkey: a quantitative comparison. Science 198: 855-857.

MOUNTCASTLE. V.B. (1974) Sensory receptors and neural encoding: introduction to sensory processes. In Medical Physiology Vol. 1: 285-306. C. V. Mosby: St. I.ouis.

PONTEN. B. (1960) Grafted skin. Acta Chir. Scand. Suppl. 257: 1-77.

RIDLEY, A. (1968) Silver staining of the innervation of Meissner corpuscles in peripheral neuropathy. Brain 91: 539-552.

RIDIEY, A. (1970) A biopsy study of the innervation of forearm skin grafted to the finger tip. Brain 93: 547-554.

RUCH. T.C. (1955) Somatic Sensation. In Textbook of Physiology, Ch. 18. p. 302, ed. J.F. Fulton, W. B. Saunders, Inc.: Philadelphia.

SINCLAIR, D. (1967) Cutaneous Sensation. Oxford University Press: London, p. 306.

STRAUCH. B. and TZUR. H. Restoration of sensation to the hand by a free neurovascular flap from the first web space of the foot. Plast. Reconstr. Surg. 62: 361-367.

TERZIS, J. K. (1977) Principles, practices, and techniques of peripheral nerve surgery. In Reconstructive Microsurgery, ed. R.K. Daniel and J.K. Terzis, Ch. 9. Little, Brown and Co.: Boston.

WEBER, E. H. (1852) Ueber den Raumsinn und die Empfindungskreise in der Haut und im Auge. Ber. Sachs Ges. Wiss. Math-Phys. Cl: 85-164.

WEINSTEIN, S. (1969) Intensive and extensive aspects of tactile sensitivity as a function of body part. sex and laterality. In The Skin Senses, ed. D. R. Kenshalo, pp. 195-222. C.C. Thomas: Springfield, III. 